\title{
PENGELOLAAN MODEL PEMBINAAN TAHFIZ ALQURAN
}

\section{MANAGEMENT OF TAHFIZ ALQURAN GUIDANCE MODEL}

\author{
H Bisri1 ${ }^{1 a}$ dan MB Abdillah \\ 1 Program Studi Manajemen Pendidikan Islam, Fakultas Keguruan dan Ilmu Pendidikan, \\ Universitas Djuanda Bogor, Jl. Tol Ciawi No. 1 Kotak Pos 35 Ciawi Bogor 16720 \\ a Korespondensi: Hasan Bisri, Email: hasan.bisri@unida.ac.id \\ (Diterima: 16-03-2018; Ditelaah: 16-03-2018; Disetujui: 27-04-2018)
}

\begin{abstract}
This study aims to obtain data about the process of fostering tahfiz Al-Quran and evaluation tahfiz Al-Quran development that is applied in Boarding School of Tahfiz Al-Quran Bina Madani Ciawi Bogor. The research approach uses qualitative approach of case study type of intrinsic case study form. Sources of data in this case study include the main subject of priecher or Alquran teachers who hold halaqah Al-Quran, students, priecher caregiver cottage, a number of teachers and administrators Bina Duta Madani Foundation. Research data collected through multimetode that is interview, observation, and documentation. Data analysis using Miles and Huberman analysis model. The analysis process includes data collection, data reduction, data display, and verification. Based on the results of research known tahfiz coaching model was done by talqin, tasmi ', muroja'ah, and ta'lim tajwid and tahsin. The rote evaluation program for student is conducted intensively. This evaluation includes daily, weekly, monthly, quarterly, and semester evaluations. This activity involves musyrif halaqah and notes its progress in kasyfu mutaba'ah yaumiyah and reports it to caregivers and foundations. The results of the achievement of memorization of the santri if it is seen from the average level has not been as expected.
\end{abstract}

Keywords: Al-Quran, Bina Madani, coaching, model, tahfidz.

\section{ABSTRAK}

Penelitian ini bertujuan untuk memperoleh data tentang proses pembinaan tahfiz Al-Quran dan evaluasi pembinaan tahfiz Al-Quran yang diterapkan di Pondok Pesantren Tahfiz AlQuran Bina Madani Ciawi Bogor. Pendekatan penelitian menggunakan pendekatan kualitatif jenis studi kasus bentuk intrinsic case study. Sumber data pada penelitian kasus ini meliputi subyek utama yaitu para ustadz atau guru tahfiz yang memegang halaqah Al-Quran, santri, ustadz pengasuh pondok, sejumlah guru serta pengurus Yayasan Bina Duta Madani. Data penelitian dikumpulkan melalui multimetode yaitu wawancara, observasi, serta dokumentasi. Analisis data menggunakan model analisis Miles dan Huberman. Proses analisis meliputi pengumpulan data, reduksi data, display data, dan verifikasi. Berdasarkan hasil penelitian diketahui model pembinaan tahfiz di Pondok Pesantren Tahfiz Al-Quran Bina Madani Putra Ciawi Bogor dilakukan dengan cara talqin, tasmi', muroja'ah, dan ta'lim tajwid dan tahsin. Program evaluasi hafalan bagi para santri dilakukan secara intensif. Evaluasi ini mencakup evaluasi harian, mingguan, bulanan, triwulan, dan semester. Kegiatan ini melibatkan musyrif halaqah dan mencatat perkembangannya dalam kasyfu mutaba'ah yaumiyah serta melaporkannya kepada pengasuh dan yayasan. Hasil pencapaian hafalan keitqan-an para santri jika dilihat dari tingkat rata-rata belum sesuai harapan.

Kata kunci: Alquran, Bina Madani, model, pembinaan, tahfiz. 
Bisri, H., dan Abdillah, M.B. (2018). Pengelolaan Model Pembinaan Tahfiz Al-Quran. Tadbir Muwahhid, 2(1), 60-72.

\section{PENDAHULUAN}

Pesantren adalah salah satu lembaga pendidikan Islam yang ada di Indonesia yang mempunyai peranan yang sangat besar dalam proses pengembangan serta penyebarluasan tahfiz Al-Quran. Dalam perkembangannya, pesantren semakin memperluas bidang kegiatannya tidak hanya pada peningkatkan hubungan vertikal yaitu hubungan antara hamba dengan Allah melalui pembelajaran keagamaan, tetapi juga hubungan horizontal antarsesama manusia atau kesadaran sosial. Pesantren kini tidak bisa lagi dinilai sebagai lembaga keagamaan murni semata, tetapi juga menjadi lembaga sosial yang hidup dan terus menerus merespon persoalan masyarakat di sekitarnya (Husein, 2003). Pesantren dengan mendasarkan pada ajaran dan nilai-nilai Al-Quran mampu menjadi sumber solusi dalam memecahkan permasalahan kehidupan individu dan sosial.

Pesantren di tengah masyarakat berperan dan berfungsi sebagai lembaga ritual, lembaga pembinaan moral, lembaga dakwah dan yang paling populer adalah sebagai institusi pendidikan Islam. Pendidikan di pesantren meliputi pendidikan Islam, dakwah, pengembangan masyarakat dan pendidikan lainnya yang sejenis. Dan salah satu kegiatan pendidikan pesantren yang sedang marak adalah kegiatan menghafal Al-Quran.

Pendidikan Al-Quran seperti menghapal (tahfiz) Al-Quran berkembang secara pesat di masyarakat. Menghafal Al-Quran merupakan kegiatan unggulan yang dikembangkan di pondok-pondok pesantren termasuk juga diterapkan di sekolah formal baik swasta maupun negeri. Di lembaga pendidikan Islam terpadu secara khusus seperti SD Islam Terpadu (SDIT) memiliki program unggulan tahfiz Al-Quran. Akan tetapi, program-program pendidikan tahfiz Al-Quran yang diselenggarakan di lembagalembaga pendidikan yang ada belum berjalan secara efektif dan maksimal. Pencapaian hasil program tahfiz Al-Quran belum sesuai dengan target yang diharapkan. Kondisi itu disebabkan oleh berbagai macam faktor baik internal maupun eksternal. Faktor internal yaitu kondisi pada anak peserta program sedangkan faktor luar seperti lingkungan yang kurang mendukung, waktu yang terbatas, guru tahfiz yang kurang ahli dibidangnya, serta tidak memiliki model pembinaan tahfiz Al-Quran yang tepat, efektif, dan efisien.

Al-Quran selain dibaca dan direnungkan juga perlu untuk dihafal, dipindahkan dari tulisan ke dalam dada, karena hal ini merupakan tanda orang yang berilmu. Allah berfirman dalam surat Al-Ankabut ayat 49:

Artinya:Sebenarnya, Alquran itu adalah ayat-ayat yang nyata di dalam dada orangorang yang diberi ilmu. dan tidak ada yang mengingkari ayat-ayat Kami kecuali orangorang yang zalim.

Para ulama menghafalnya dan Allah SWT selalu memberikan kemudahan. Al-Quran tersimpan dan terpelihara dalam dada dengan dihapal oleh banyak kaum muslimin turun temurun dan dipahami oleh mereka, sehingga tidak ada seorangpun yang dapat mengubahnya. Al-Quran mudah dibacakan oleh lidah, selalu terpelihara dan terawat dalam hati, dan mengandung mukjizat, baik lafaznya maupun maknanya. Al-Quran bisa terjaga dari zaman Rasulullah SAW sampai 
dengan sekarang salah satunya adalah dengan cara dihafal (Al-Mubarakfuri, 2012).

Tahfiz Al-Quran adalah suatu proses mengingat di mana seluruh materi ayat (rincian bagian-bagiannya seperti harakat, wakaf dan lain-lain) harus diingat secara sempurna (Sa'dullah, 2008). Kata tahfiz (menghafal) adalah aktifitas merekam apa yang kita baca dan kita pahami (Hidayatullah, 2010). Definisi lain dari kata tahfiz Al-Quran secara sederhana adalah membaca dengan lisan sehingga menimbulkan ingatan dalam pikiran dan meresap masuk dalam hati untuk diamalkan dalam kehidupan sehari-hari. Menurut Munir,huffazh Quran adalah orang yang dengan tekun, cermat dan teliti dalam membaca, menghafal dan memelihara ayat demi ayat dari Alquran. Dengan kata lain, orang yang telah menjadikan Alquran bagian dari kehidupannya (Munir, 2005).

Di masyarakat, sejumlah lembaga pendidikan yang menyelenggarakan kegiatan tahfiz, antara lain Pondok Pesantren Tahfiz Al-Quran Bina Madani Ciawi Bogor, Universitas Djuanda dengan Program Pendidikan Kader Dakwah (PKD UNIDA), dan Lembaga Kaderisasi Imam dan Da'i(LKiD) Puncak Bogor. Dalam program PKD UNIDA, program hafalan Al-Quran diikuti oleh mahasiswa. Jumlah hafalan yang diprogramkan sebanyak 1 juz persemester. Jadi, ketika memasuki semester 7 para peserta diharapkan memiliki hafalan 7 juz(Bisri, 2013). Sedangkan di LKiD, para peserta adalah santri-santri yang telah lulus seleksi hafalanAl-Quran. Program hafalan yang diselenggarakan lebih singkat daripada program PKD UNIDA, yaitu 30 juz dalam waktu 1 tahun.

Pondok pesantren Bina Madani merupakan lembaga pendidikan Islam yang berorientasi pada program tahfiz Al-Quran.
Lulusan Pondok Pesantren Tahfiz Al-Quran Bina Madani diharapkan memiliki ilmu qira'ah,generasi penghafal Al-Quran bersanad yang berakhlaq karimah, cerdas dan berilmu luas.

Upaya yang dilakukan untuk mencapai mutu lulusan dengan mendatangkan Ahmad Al Ramadi dari Yaman yang memiliki sanad qira'ah 'asyarah atau keahlian sepuluh cara membaca Al-Quran dengan sanad muttasil sampai kepada Rasulullah s.a.w. Di samping itu, mendatangkan seorang qari' bersanad dari Sudan untuk melanjutkan program sanad Al-Quran bagi para santri yang telah menyelesaikan hafalan.

Program lainnya berupa pengajaran bahasa Arab, bahasa Inggris dan ilmu-ilmu pengetahuan umum lainnya sebagaimana diajarkan di sekolah formal. Para santri diharapkan mampu memahami ilmu Islam dengan kemampuan bahasa Arab dan mampu mengikuti perkembangan zaman dengan bahasa Inggris dan ilmu pengetahuan lain. Kemampuan tersebut menjadi modal santri dalam mempelajari khazanah-khazanah keilmuan yang dilandasi oleh Al-Quran.

Kegiatan tahfiz Al-Quran di Pondok Pesantren Bina Madani Ciawi memiliki model yang khas. Para santri diharapkan mampu menghafal Alquran dengan target yang telah ditentukan. Jumlah hafalan $\mathrm{Al}$ Quran sebanyak 30 Juz selama dua setengah tahun atau lima semester. Kemudian para santri mendapatkan program itqan(pemantapan hafalan) selama satu semester. Pada tahun ketiga atau lulus Sekolah Lanjutan Tingkat Pertama (SLTP) menuju kejenjang Sekolah Lanjutan Tingkat Atas (SLTA) para santri diharapkan sudah memiliki hafalan yang itqan(lancar).

Para santri juga dituntut untuk mengikuti kegiatan belajar mengajar sebagaimana 
sekolah umum. Santri masuk kelas setiap hari. Untuk memenuhi kebutuhan pendidikan formal, pondok pesantren (Ponpes) menjalin kerjasama dengan sekolah di sekitar Ponpes baik tingkat SMP maupun SMA. Para santri mendapat bimbingan intensif untuk memahami materi-materi bidang studi khususnya yang di-UN-kan pada saat menjelang pelaksanaan UN. Kegiatan bertujuan untuk menghasilkan generasi Qurani yang berkualitas dengan wawasaan luas.

Pondok Pesantren Bina Madani telah mencetak para penghafal Al-Quran yang tersebar di seluruh Indonesia. Lulusan telah menyelesaikan hafalan 30 juz sesuai dengan target yang ditentukan. Ujian dilaksanakan dengan cara membaca Al-Quran keseluruhan bil hifdz di masjid jami' Pondok Pesantren Bina Madani selama tiga hari dan disimak oleh seluruh santri. Ketika acara wisuda, santri huffadz terbaik akan diuji oleh para tamu undangan dengan cara ditanya secara acak dari ayat-ayat Al-Quran kemudian santri diminta untuk melanjutkan ayat tersebut. Selain itu juga ada demonstrasi hafalan matan jazari sebagai kitab dasar sebelum belajar ilmu qira'ah. Pada tahun 2013, ada beberapa santri yang telah menyelesaikan hafalan lebih cepat dari target yang telah ditentukan. Hal itu menunjukkan bahwa Pondok Pesantren Bina Madani berusaha untuk menghasilkan para huffadz yang benar-benar itqan dalam hafalannya(Musrif, 2014).

Di bidang akademik, para santri memiliki kemampuan memadai. Para santri mampu bersaing dengan para siswa sekolah umum yang menjadi sekolah induk dari pondok pesantren Bina Madani. Hal itu ditunjukan dengan beberapa santri yang memperoleh nilai tertinggi pada sejumlah materi ujian seperti pelajaran bahasa Inggris, matematika dan mata pelajaran lain.
Penelitian mengenai model pembinaan tahfiz Al-Quran dianggap perlu untuk dilakukakan dalam rangka memperoleh model tahfiz Al-Quran yang efektif dan efisien untuk mengembangkan kualitas pembinaan tahfiz Al-Quran. Dengan demikian,penelitian tentang model pembinaan tahfiz Al-Quran di Pondok Pesantren Tahfiz Al-Quran Bina Madani Ciawi Bogor dapat menjadi alternatif untuk memperoleh pembelajaran yang bermanfaat bagi pengembangan pesantren tahfiz di tanah air.

Penelitian berusaha untuk menjawab permasalahan bagaiman model pembinaan tahfiz Al-Quran di Pondok Pesantren Tahfiz Bina Madani. Subfokus dari penelitian terutama dibatasi pada proses pembinaan tahfiz Al-Quran dan evaluasi.

\section{MATERI DAN METODE}

Penelitian bertujuan untuk memperoleh data tentang: 1) proses pembinaan tahfiz AlQuran dan 2) evaluasi pembinaan tahfiz AlQuran yang diterapkan di Pondok Pesantren Tahfiz Al-Quran Bina Madani Putra Ciawi Bogor.

Pendekatan penelitian menggunakan pendekatan kualitatif jenis studi kasus. Bentuk studi kasus yang digunakan yakni intrinsic case study. Sumber data pada penelitian kasus ini meliputi subyek utama penelitian yaitu para ustadz atau guru tahfiz yang memegang halaqah Al-Quran, santri, ustadz pengasuh pondok serta sejumlah guru yang terlibat dalam proses pembinaan santri selama di pondok pesantren Bina Madani.Selain itu, pengurus Yayasan Bina Duta Madani yang telah berperan dalam mendirikan Ponpes Bina Madani.Sumber data lain yang digunakan berasal dari dokumen, catatan resmi sekolah, foto-foto 
liputan sekolah, artikel koran, majalah, serta liputan lain yang relevan.

Data penelitian dikumpulkan melalui multimetode yaitu: wawancara, observasi, serta dokumentasi. Analisis data menggunakan model analisis Miles dan Huberman atau flow model analysis. Proses analisis mencakup empat aktifitas, yaitu: pengumpulan data, reduksi data, display data, dan verifikasi (menarik kesimpulan).

\section{HASIL DAN PEMBAHASAN}

\section{Hasil}

\section{Gambaran Umum}

Pondok Pesantren Tahfiz Bina Madani Ciawi berdiri tahun 2005. Pesantren ini didirikan H. Masrur Samhari, H. Mustholah Maufur, M.A, dan Dr. H. Yusuf Hidayat. Gagasan awal pendirian pesantren berawal untuk mendirikan pesantren mahasiswa. Selain itu, kurangnya minat masyarakat yang mempelajari ilmu agama khususnya AlQuran dibandingkan dengan masyarakat yang mempelajari ilmu umum.

Pondok Pesantren Tahfiz Bina Madani salah satu amal usaha Yayasan Bina Duta Madani Jakarta. Semenjak tahun 2010, Pondok Pesantren Tahfiz Al-Quran Bina Madani merupakan lembaga pendidikan berbasis Al-Quran dengan jenjang pendidikan enam tahun. Pesantren didasarkan pada pondasi iman berasaskan Al-Quran dan As-Sunnah. Pesantren berupaya melahirkan generasi muslim yang berjiwa Qurani. Santri didik menjadi muslim sholeh yang hafal 30 juz, beraqidah lurus, berakhlak mulia, dan menjadi teladan yang baik serta siap berdakwah dalam kebenaran dan kesabaran.

Pondok Pesantren Tahfiz Bina Madani memiliki visi menjadi lembaga pendidikan tahfiz Al-Quran yang unggul dan pencetak generasi penghafal (hafiz) Al-Quran yang bersanad, berakhlaq karimah, cerdas, dan berilmu luas. Pondok Pesantren Tahfiz Bina Madani mengemban misi:

1. Menyelenggarakan proses belajar dan mengajar yang menyenangkan, kreatif dan inovatif dalam segala bidang termasuk bahasa arab dan bahasa inggris.

2. Menyediakan tempat yang ideal untuk belajar Allquran, mengajarkan dan menghafalnya.

3. Menjadi tempat untuk beramal guna meninggikan kalimah Allah s.w.t.

4. Menjadikan semua yang dilihat, didengar dan dirasakan sebagai sarana untuk mendidik.

5. Menyediakan sumber daya manusia (SDM) yang berkualitas.

\section{Keadaan Santri}

SantriPondok Pesantren Tahfiz Bina Madani berasal dari berbagai daerah, baik berasal dari pulau Jawa maupun dari luar Jawa. Menurut Ustadz Achmad Rifa'i, jumlah santri tahun ajaran 2013/2014 sebanyak 75 santri. Mereka terdiri dari kelas 1,2,3 SMP dan 1 SMA.Kelas satu SMP berjumlah 22 santri, kelas dua (23 santri), kelas tiga (20 santri), dan kelas satu SMA berjumlah 10santri.

Para santri tinggal di asrama yang telah disediakan oleh pondok dan menjadi kewajiban bagi setiap santri untuk tinggal di asrama. Hal itu untuk mempermudah pihak pesantren dalam pemantauan kegiatan sehari-hari santri. Kegiatan yang harus dijalani santri setiap hari adalah kegiatan kelas, halaqah, dan kegiatan di luar kelas (ekstrakurikuler). Kegiatan tambahan di luar kelas diharapkan dapat menjdi bekal dan juga pengembangan potensi yang 
dimiliki oleh santri. Bentuk kegiatan ekstrakurikuler antara lain: ketangkasan (beladiri), pidato tiga bahasa (Arab, Inggris dan Indonesia), renang, bulu tangkis.

\section{Tenaga Pengajar}

Pondok pesantren tahfiz Bina Madani memiliki guru yang berasal dari berbagai lembaga pendidikan dalam dan luar negeri. Mereka bertugas sesuai dengan bidangnya masing-masing. Tenaga pengajar di pesantren Bina madani diantaranya berasal dari alumni Universitas Islam Madinah, Universitas AntarBangsa Pakistan, Universitas Malaya Malaysia, Universitas Islam Imam Muhammad bin Su'ud Jakarta, Universitas Indonesia dll.

Para muhafidz juga berasal dari berbagai lembaga tahfiz di Indonesia, antara lain berasal dari Pondok Pesantren Tahfiz Taruna Alquran Yogyakarta, Ponpes tahfiz Ar-Royyan Cirebon, Lembaga Kaderisasi Imam dan Da'i (LKID) Cisarua Bogor serta alumni dari pesantren Bina Madani. Muhafidz yang telah memiliki ijazah sanad Alquran berasal dari Sudan.

\section{Penerimaan dan Penyeleksian Santri}

Proses penyeleksian dilakukan untuk memperoleh input santri yang memiliki kualifikasi dan dinilai mampu menyesuaikan dengan kegiatan pesantren. Sebelum mendaftarkan dirinya calon santri harus memenuhi syarat-syarat pendaftaran yang telah ditentukan. Setelah calon santri memenuhi persyaratan selanjutnya akan diikutsertakan dalam penyeleksian.

Menurut ustadz Atep Anshori ada tiga aspek penilaian yang menjadi poin utama dalam kelulusan calon santri, yaitu: 1) kesungguhan dalam karantina, 2) hasil psikotes, dan 3) kader.

1. Kesungguhan dalam karantina; kesungguhan dalam karantina bisa diketahui dari pengamatan para guru terhadap calon santri ketika karantina. Aspek yang dinilai mencakup adab calon santri terhadap ustadz dan teman, kesungguhan dalam menghafal Alquran serta disiplin waktu selama kegiatan karantina.

2. Hasil Psikotes; hasil psikotes ditentukan oleh ahli psikologi yang telah ditunjuk oleh pesantren. Penilaian dan informasi berkenaan tentang kepribadiankepribadian calon santri yang mengikuti psikotes. Psikolog memberikan rekomendasi apakah calon santri tersebut lulus atau tidak.

3. Kader; calon santri memiliki potensi dakwah bagi daerah atau keluarganya. Calon santri misalnya berasal dari daerah yang mayoritas non muslim, dari daerah yang terpencil, dan lain-lain.

\section{Program Kegiatan Santri}

Pondok pesantren tahfiz Al-Quran Bina Madani merupakan pondok pesantren yang menyelenggarakan program tahfiz Al-Quran tanpa mengesampingkan pendidikan formal. Para santri mengikuti kegiatan sekolah setiap hari kecuali hari kamis dan jumat. Waktu belajar dimulai pada jam 08.00 sampai dengan jam 10.45. Jumlah mata pelajaran yang dipelajari sebanyak 4 mata pelajaran. Jenis mata pelajaran terdiri dari ilmu-ilmu syar'i dan ilmu umum sesuai yang diujikan pada Ujian Nasional. Pengkajian terhadap ilmu-ilmu syar'i sebagai ilmu pendukung dalam memahami Alquran.

Program tahfiz Alquran di pesantren Bina Madani telah berjalan sejak awal berdirinya dan mengalami peningkatan dalam pembinaan serta pengelolaannya. Pada awal berdirinya, para santri menyetorkan hafalannya kepada salah seorang pengurus pesantren. Kegiatan tahfiz belum terkelola 
dengan maksimal karena berbagai macam kendala. Pesantren Bina Madani mengalami peningkatan pembinaan tahfiz Alquran setelah kehadiran para guru hafiz Alquran dan kedatangan ustadz Yulio Muslim Dacosta, Lc.

Model pembinaan tahfiz Alquran di pesantren tahfiz Alquran Bina Madani terdiri dari empat komponen utama, yaitu: penyeleksian santri, proses pembinaan tahfiz Alquran, evaluasi pembinaan tahfiz, dan proses pengelolaan SDM.

\section{Pembahasan}

\section{Kegiatan Pembinaan Tahfiz Al-Quran}

Pembinaan tahfiz Al-Quran di Bina Madani dilaksanakan dengan adanya koordinasi antar-musyrif halaqah yang dipimpin oleh bagian idarah. Di Pesantren Bina Madani penanggung jawab tahfiz sering disebut idaratu-tahfiz (إدارة التحفيط). Idarahtahfiz memiliki peran sebagai manajer dalam proses pembinaan tahfiz di Bina Madani. Menurut ustadz Saifullah ada empat unsur utama yang menjadi tugas idarahtahfiz, yaitu:

1. Perencanaan; mampu menghasilkan alumni pesantren Bina Madani yang hafal Alquran bersanad, berakhlak mulia, dan berpengetahuan luas.

2. Pengaturan; bagian idarah tahfiz mengatur dengan membuat kurikulum tahfiz yaitu pencapaian target hafalan persemester.

3. Pembinaan; proses pembinaan terpusat dalam kegiatan halaqahAlquran yang dilaksanakan setiap hari empat kali.

4. Pemantauan; pemantauan yang dilaksanakan oleh idarah tahfiz dengan mengadakan ujian hafalan.

Pembinaan tahfiz Al-Quran semuanya bersumber dari halaqah Al-Quran. Halaqah
Al-Quran adalah berkumpulnya beberapa orang di sebuah tempat yang suci untuk belajar Al-Quran dalam waktu tertentu (Attulaimat, 2000). Kegiatan pembinaan hafalan santri di Ponpes Bina Madani terpusat dalam kegiatan halaqah Alquran tetapi bukan berarti diluar halaqah tidak ada kontrol. Santri tetap terpantau kegiatan hafalannya dengan adanya buku catatan harian (كثف المتابعة) yang dibawa oleh musyrif halaqah. Di dalamnya tercatat dengan detil jumlah setoran hafalan baru santri setiap hari selama satu bulan, jumlah muroja'ah atau mengulang hafalan serta evaluasi mingguan.

Pesantren Bina Madani membagi seluruh santri menjadi delapan halaqah. Masingmasing halaqah berjumlah tujuh sampai delapan santri. Halaqah Al-Quran dilaksanakan sebanyak empat kali setiap hari. Waktunya pada ba'da subuh sampai jam tujuh, ba'da dzuhur sampai jam 13.30, ba'da asar sampai jam 16.30 dan ba'da isya' sampai jam 20.45. Jadi, total waktu halaqah dalam sehari sekitar 5 jam. Kegiatan dalam halaqah yang utama ada empat kegiatan, yaitu:

\section{Talqin التلقين}

Talqin secara bahasa berarti memahamkan, sedangkan menurut istilah adalah mengajarkan ucapan, kata-kata atau ayat dalam Alquran yang kemudian ditirukan oleh santri atau pendengar(Attulaimat, 2000). Apabila ada kekurangan atau kesalahan dalam pengucapan seperti panjang pendek, makhraj al-huruf dan sifat huruf maka ustadz langsung membetulkannya. Talqin ini wajib bagi para anak-anak dan pemula yang ingin menghafalkan Alquran dan belum memiliki bacaan yang baik dan benar. Dan juga bagi orang dewasa yang merasa kesulitan membaca Alquran. Kegiatan talqin dalam halaqah di Bina Madani wajib bagi setiap 
santri yang akan menyetorkan hafalan. Ada dua macam talqin, yaitu talqin fardi atau sendiri-sendiri antara ustadz dengan satu orang santri dan talqin jama'i atau bersamasama antara satu ustadz dengan dua santri atau lebih.

\section{Talqin Fardi التلقين الفردي}

Talqin fardi dilaksanakan oleh santri bersama musyrifnya setiap hari setelah menyetorkan hafalan baru. Waktunya menyesuaikan setoran santri, antara halaqah pagi hari $b a^{\prime} d a$ subuh atau sore hari setelah asar. Kegiatan talqin dilaksanakan sebagai persiapan hafalan yang akan disetorkan besok hari. Biasanya ayat-ayat yang ditalqin sebanyak satu halaman atau menyesuaikan jumlah setoran hafalan santri.

Ada tiga cara dalam melaksanakan talqin fardi, yaitu:

1. Ustadz membacakan surat, ayat atau kalimat dalam Alquran dengan suara yang lantang dan jelas di depan santri kemudian meminta santri tersebut untuk mengulangi apa yang sudah didengar.

2. Santri membacakan ayat yang akan dihafalkan. Apabila terdapat kesalahan dalam membaca seperti sifat huruf, makhariju al-huruf maka ustadz membetulkannya.

3. Santri mendengarkan kaset atau rakaman seorang qari yang direkomendasikan oleh ustadz. Di Bina Madani sendiri salah satu qari' yang direkomendasikan adalah ustadz Murtadlo seorang qari' yang bersanad dan berasal dari Indonesia.

\section{Talqin jama'i التلقين الجماعي}

Talqin jama'i dilaksanakan seperti talqin fardi tetapi secara bersama-sama dengan seorang ustadz atau bisa juga dengan menggunakan video.

Talqin jama'i di pesantren Bina Madani dilaksanakan setiap minggu sekali. Tepatnya, sabtu malam atau malam mingguba'da Maghrib di Masjid. Kegiatan ini diikuti oleh seluruh santri bersama ustadz yang telah ditunjuk atau menyesuaikan jadwal. Selain itu, talqinjama'i juga dilaksanakan bersama-sama di halaqah masing-masing. Pelaksanaan talqinjama'i biasanya dilaksanakan akhir pekan bersama musyrif halaqah.

Kegiatan talqin terus dilaksanakan sampai santri menyelesaikan hafalannya 30 juz. Setelah menyelesaikan setoran hafalan Alquran, santri juga diminta mengikuti program intensif talqin 30 juz. Menurut ustadz Saifullahkegiatan talqin bertujuan untuk meminimalisir kesalahan dalam hafalan.

\section{Tasmi'(التسميع)}

Tasmi' secara bahasa berarti memperdengarkan. Sedangkan secara istilah adalah menyetorkan hafalan Alquran kepada ustadz dalam sebuah halaqah(Attulaimat, 2000). Kegiatan tasmi' di pesantren Bina Madani dilaksanakan setiap hari sekali. Waktunya ketika halaqah intensif antara ba'da subuh atau ba'da asar. Tujuannya untuk memberikan keluasan kepada santri untuk menentukan waktu menyetorkan hafalan yang sesuai.

Kegiatan tasmi' dilaksanakan setiap hari kecuali hari libur yaitu hari jumat. Jumlah hafalan yang disetorkan atau ditasmi'kan minimal satu halaman atau menyesuaikan dengan kesepakatan santri. Namun, apabila ada yang tidak menyetorkan atau tidak sesuai target, musyrif akan menanyakan sebabnya dan memberikan arahan serta nasehat. Setiap musyrif halaqah diwajibkan untuk menulis perkembangan hafalan santri 
di dalam buku mutaba'ah hifdzu Alquran atau buku catatan hafalan Alquran. Sehingga penanggung jawab tahfiz di Bina Madani mampu melihat perkembangan santri dalam menghafal Alquran.

\section{Muroja'ah (المراجعة)}

Muroja'ah secara bahasa adalah pembiasaan. Sedangkan menurut istilah adalah kegiatan mengulangi hafalan Alquran(Attulaimat, 2000). Muroja'ah harus dilakukan dan wajib bagi para penghafal Alquran. Mengulangi hafalan membutuhkan keistiqamahan dan ketekunan untuk mencegah lupa atau hilangnya hafalan. Muroja'ahAlquran yang diterapkan di pesantren Bina Madani ada tiga metode.

\section{a. Muraja'ah dengan musyrif}

Kegiatan mengulangi hafalan bersama musyrif halaqah dilaksanakan ketika dalam halaqah intensif antara ba'da asar atau ba'da subuh menyesuaikan waktu setoran. Apabila waktu setoran santri tersebut pagi ba'da subuh maka waktu muroja'ah dengan musyrif halaqah sore hari ba'da asar begitu juga sebaliknya. Muraja'ah dengan musyrif jumlahnya maksimal setengah juz atau menyesuaikan persetujuan antara santri dan musyrif halaqah. Kegiatan ini dilakukan secara bergiliran dengan teman halaqah yang lain.

\section{b. Muraja'ah dengan teman}

Muraja'ah dengan teman dilaksanakan ketika halaqah ba'da dzuhur dan ba'da isya. Kedua waktu tersebut adalah waktu khusus yang disediakan oleh pesantren untuk melakukan muroj'ah bersama teman. Muraja'ah dengan teman bisa juga dilaksanakan diluar waktu tersebut. Kegiatan ini bersifat fleksibel menyesuaikan waktu dan keadaan teman yang akan menyimakkan hafalan begitu juga dengan jumlah hafalan yang diulanginya.

\section{c. Muraja'ah fardiah atau mengulang hafalan sendiri.}

Muraja'ah Fardiah dilaksanakan sesuai inisiatif santri dengan menyesuaikan target yang telah disepakati bersama musyrif halaqah. Berdasarkan pengamatan lapangan, muroja'ah fardiah sangat membutuhkan kesadaran diri dari setiap santri. Ada yang sehari mencapai lima juz, tiga juz. Santri dalam mengulangi hafalan ada yang dengan membaca bi an-nadzar melihat ke mushaf atau dengan tanpa melihat ke mushaf, tetapi apabila ada kesalahan baru membuka mushaf. Muraja'ah fardiah juga bisa dilakukan ketika ada kesempatan untuk mengulang hafalan. Ada yang mengulang hafalan sambil menunggu antrian kamar mandi, pergantian pelajaran atau sebelum tidur.

Kegiatan muroja'ah dengan ketiga cara diatas dipantau oleh musyrif halaqah dengan menanyakan jumlah muroja'ah yang diperoleh selama satu hari, dan mencatatnya di lembar catatan harian.

Ta'lim Tajwid dan Tahsin تعليم التجويد و تصديح (التلاوة)

Tajwid di pesantren Bina Madani dipelajari secara teori dan praktek. Menurut ustadz Saifullah tajwid pembelajaran tajwid dibagi menjadi dua, yaitu 'amali (praktek) dan teori. Praktek dalam ilmu tajwid mencakup di dalamnya makharij al-huruf dan tahsin attilawah, dan salah satu teknik dari tahsin attilawah adalah talqin.

Teori tajwid dipelajari di kelas pada saat pagi hari. Santri kelas satu menggunakan buku Pedoman Daurah Alquran karya Abdul Aziz Abdur Rauf, Al Hafiz, Lc. Sedangkan kelas dua dan tiga menggunakan kitab Matan Al-Jazariah karya Syekh Ibnu Jazari. Matan Jazariah merupakan kitab yang berisi nadzam atau bait-bait syair arab yang menjelaskan tentang teori ilmu tajwid. Ada 
109 bait dalam kitab ini. Bait-bait tersebut harus dihafal dan disetorkan kepada guru pengajarnya.

Untuk kelas tiga dan empat yang sudah menyelesaikan hafalan, diadakan kegiatan daurah atau seminar matanTuhfatul Athfal wal Ghilman. Matan Tuhfatul Athfal adalah bait-bait syair arab (nadzam) yang membahas tentang kaedah ilmu tajwid. Matan ini berisikan 61 bait yang ditulis oleh Imam Sulaiman Aljamzuri, dimulai dengan muqoddimah, kemudian dilanjutkan dengan hukum tanwin dan nun sakinah, ghunnah, mim sukun, lam pada alif lam dan lam fi'il, idghom mutaqooribayn, mutajanisain, mutamatstsilayn, mad ashli dan mad far'iy, mad wajib mad jaiz dan mad laazim, kemudian diakhiri dengan penutupan. Kegiatan ini dilaksanakan selama satu setengah bulan bersama ustadz Saifullah selaku penanggung jawab tahfiz di Ponpes Bina Madani. Bagi peserta yang telah menyelesaikan hafalan bait syair tuhfatul Athfal dan dinyatakan lulus oleh ustadz Saifullah berhak mendapatkan sanad tuhfatul Athfal. Ustadz Saifullah sendiri telah mendapatkan sanad tuhftul Athfal dan matan Al-Jazariah dari Syekh Ibrahim, seorang qari' bersanad yang diutus oleh Lembaga Penghafal Alquran Dunia untuk wilayah Indonesia.

Selain teori, tajwid dan tahsin tilawah juga dipraktekkan dalam proses menghafal Alquran. Tajwid dan tahsin dilaksanakan bersamaan dengan proses talqin baiktalqin fardi maupun talqin jama'i.

\section{Evaluasi Pembinaan Tahfiz}

Dalam proses pembinaan tahfiz sangat perlu diadakan evaluasi. Evaluasi hafalan santri bermanfaat untuk mengetahui tingkat keberhasilan pembinaan yang telah dilaksanakan. Menurut Ustad Saifullah ada dua macam evaluasi hafalan yang dilaksanakan di pesantren Bina Madani berdasarkan waktu dan berdasarkan pencapaian yang diperoleh (marhalah).

\section{Evaluasi Berdasarkan Waktu}

Evaluasi pembinaan tahfiz jika dilihat berdasarkan waktu pelaksanaannya, terdiri dari:

a. Harian; Evaluasi harian dilaksanakan antara santri dengan musyrif halaqah berupa pemantauan hafalan dan muroja'ah. Semua kegiatan ini tercatat dalam kasyfu mutaba'ah al yaumiyah atau buku catatan harian.

b. Mingguan; Ujian halaqah mingguan yaitu ujian pencapaian mingguan. Pelaksanaanya dengan menyetorkan hafalan atau menyimakkan ulang jumlah hafalan selama satu minggu kepada musyrif halaqah.

c. Bulanan; Pencapaian dalam sebulan akan diujikan dalam bentuk soal secara lisan. Menyesuaikan catatan dalam kasyfu mutaba'ah selama satu bulan tersebut. Melalui ujian ini akan diketahui jumlah pencapaian hafalan dan jumlah hafalan yang itqan. Hasil ujian bulanan menjadi bahan yang dilaporkan ke pengasuh pesantren dan yayasan.

d. Triwulan; Evaluasi Triwulan atau midsemester dilaksanakan selama satu minggu dengan cara menyimakkan tiga juz terakhir yang telah disetorkan atau disimakkan.Kegiatan sima'an dilaksanakan di halaqah masing-masing bersama musyrif. Ujian ini dilaksanakan dengan memaksimalkan waktu halaqah tanpa mengganggu kegiatan sekolah. Santri diharuskan menyetorkan hafalan tiga juz terakhir dan setiap kesalahan akan dicatat dalam blanko penilaian yang sudah disediakan.

e. Semester; Evaluasi hafalan santri persemester dilaksanakan selama satu 
minggu untuk semester ganjil dan dua minggu untuk semester genap. Jumlah hafalan yang diujikan menyesuaikan kurikulum tahfiz yaitu:

$\begin{array}{ll}\text { Semester } 1 & : 4 \text { juz } \\ \text { Semester } 2 & : 6 \text { juz } \\ \text { Semester } 3 & : 6 \text { juz } \\ \text { Semester } 4 & : 7 \text { juz } \\ \text { Semester } 5 & : 7 \text { juz } \\ \text { Semester } 6 & : \text { Itqan } 30 \text { juz }\end{array}$

Ada dua bentuk ujian yang diselenggarakan, ujian tasmi' dan ujian soal. Dalam ujian tasmi' anggota halaqah diacak tidak sesuai dengan musyrif halaqah yang biasanya. Hal ini supaya musyrif halaqah bisa memberikan nilai lebih obyektif. Ujian tasmi' dilaksanakan di masjid. Ujian ini dilaksanakan di empat waktu halaqah Alquran dan mengganti kegiatan sekolah dengan ujian tasmi'. Bagi santri yang belum mencapai target tiap semester tetap mentasmi'-kan jumlah hafalan sesuai target semester tersebut. Caranya dengan menambahkan sisa hafalan yang belum tercapai dengan hafalan sebelumnya. Misalnya ujian tasmi' 6 juz sampai juz 10 tetapi baru sampai target juz 8. Maka ujian tasmi' dari juz 3 sampai juz 8. Penguji memberikan penilaian dan menulisnya dalam blanko yang sudah disediakan. Nilai sempurna adalah 100. Setiap kesalahan bernilai setengah $(0,5)$. Berikut ini adalah sistem penilaian ujian tahfizAlquran berdasarkan penjelasan ustad Wahyudi:

a. Nilai sempurna per Juz =Nilai sempurna dibagi jumlah juz

b. Nilai santri per juz = Nilai sempurna tiap juz dikurangi jumlah kesalahan

c. Total nilai santri $=$ Jumlah seluruh nilai santri tiapjuz

Setelah menyelesaikan ujian tasmi' sesuai dengan kurikulum tahfiz, santri mengikuti ujian soal. Ujian soal dilaksanakan di ruang perpustakaan bersama penanggung jawab tahfiz dan seorang musyrif halaqah yang sudah ditunjuk. Setiap santri akan ditanya dan diminta untuk melanjutkan ayat yang dibacakan oleh penguji.

\section{Evaluasi Berdasarkan Jumlah Pencapaian Hafalan(Ikhtibar Marhalah)}

Ujian marhalah adalah ujian bagi santri yang telah mencapai setoran hafalan tiga juz atau kelipatannya. Ujian ini dilaksanakan bersama penanggung jawab tahfiz. Ujian dalam bentuk soal ayat Alquran yang kemudian santri diminta untuk melanjutkannya. Waktu pelaksanaan ketika jam halaqah Alquran. Ujian ini diharapkan mampu memberikan motivasi bagi santri untuk meng-itqan-kan hafalannya. Namun dalam pelaksanaannya kegiatan ini belum berjalan secara maksimal.

Berdasarkan hasil evaluasi, diketahui hasil hafalan santri kelas satu SMPpada bulan Januari 2013 dengan pencapaian tertinggi hafalan adalah 7 juz. Sebulan kemudian, pada bulan Februari pencapaian tertinggi adalah 9 juz. Untuk tingkat hafalan yang itqan dari seluruh hafalan yang dimiliki,santri yang memiliki itqan hafalan tertinggi dengan pencapaian 9 juz.

Perolehan hapalan nilai terendah pada bulan Januari yaitu dua juz dan pada bulan Februari menjadi 3 juz. Hal ini menunjukkan peningkatan satu juz selama satu bulan. Sedangkan itqan hafalan terendah adalah dua juz pada bulan Januari.

Jumlah rata-rata hafalan santri kelas satu pada bulan Januari adalah empat juz dan pada bulan Februari meningkat menjadi 5,2 juz. Hal ini menunjukkan peningkatan pencapaian hafalan santri kelas satu adalah 1,2 juz selama satu bulan. Sedangkan itqan hafalan santri kelas satu memiliki rata-rata 3,47 juz atau dibulatkan menjadi 3,5 juz. 
Pencapaian santri kelas dua SMP tertinggi dengan pencapaian 30 juz atau telah menyelesaikan hafalan Alquran. Sedangkan keitqanan hafalannya adalah 15 juz. Pencapaian hapalan terendah sebanyak 5 juz dan itqan 3 juz.

Hasil pencapaian hafalan santri kelas 3 SMP, sekitar 12 anak telah menyelesaikan hafalan 30 juz. Untuk pencapaian nilai itqan tertinggi ada dua santri dengan hasil 25 juz. Sedangkan hasil terendah dengan pencapaian 6 juz danitqan 5 juz.

\section{KESIMPULAN DAN IMPLIKASI}

\section{Kesimpulan}

Model pembinaan tahfiz Al-Quran di Indonesia memiliki keanekaragaman sesuai sudut pandang para ustad atau guru tahfiz dalam menerapkan pola pembinaan tahfiz di lembaga yang dikelola. Salah satu model pembinaan tahfiz Al-Quran adalah model pembinaan tahfiz Al-Quran di Pondok Pesantren Bina Madani Ciawi Bogor. Ciri khas model pembinaan tahfiz Al-Quran di Pondok Pesantren Bina Madani sebagai berikut:

a. Mengajarkan tahsin al-qira'ah bagi seluruh santri sebelum memulai menghafal Alquran bersama dengan para musyrif yang kompeten dalam bidangnya. Kegiatan ini terpantau dengan cara mencatatnya dalam kasyfu mutaba'ah yaumiah. Proses pemantauan tahsin al-qira'ah sangat penting bagi para penghafal Alquran karena bacaan yang bagus bukan hanya indah didengar tetapi juga sesuai dengan kaedah makharij al-huruf dan sifat huruf.

b. Program sanad matantuhfatul athfal dan matan al jazariah bagi santri yang telah menyelesaikan hafalan. Matan tuhfatul athfal dan matan al jazariah adalah matan yang harus dihafalkan dan mendapat ijazah sanad sebelum melanjutkan program sanad Alquran.

c. Program sanad Alquranbagi santri yang telah menyelesaikan hafalan dan mendapat rekomendasi dari Syekh Hudzaifah akan melanjutkan program sanad qira'ah hafs.Program sanad Alquran masih jarang di Indonesia apalagi untuk santri tingkat SMP dan SMA. Pondok Pesantren Tahfiz Bina Madani sedang menjalankan program ini dengan mendatangkan seorang qari'Alquran bersanad yang berasal dari Sudan.

d. Para santri selain dituntut untuk menyelesaikan hafalan AlquranKamil selama tiga tahun juga tetap menjalankan kegiatan sekolah. Namun pesantren tetap menyelenggarakan kegiatan tahfiz.

e. Program evaluasi hafalan bagi para santri dilakukan secara intensif. Evaluasi ini mencakup evaluasi harian, mingguan, bulanan, triwulan, dan semester. Kegiatan ini melibatkan musyrif halaqah dan mencatat perkembangannya dalam kasyfu mutaba'ah yaumiyah serta melaporkannya kepada pengasuh dan yayasan. Hasil pencapaian hafalan keitqan-an para santri jika dilihat dari tingkat rata-rata belum sesuai harapan.

\section{Implikasi}

Berdasarkan kesimpulan hasil penelitian berimplikasi sebagai berikut:

a. Pengurus Pondok Pesantren Bina Madani Ciawi Bogor perlu menyediakan jumlah musrif yang cukup sebagai upaya untuk meningkatkan mutu program tahsin al-qira'ah. 
b. Kegiatan pada jam halaqah Alquran agar dimaksimalkan sehingga meningkatkan rata-rata hafalan ke-itqan-an para santri.

c. Pengurus Pondok Pesantren Pesantren Bina Madani dapat memberikan daurah tentang pengelolaan halaqah Alquran sebagai upaya meningkatkan mutu pembinaan tahfiz Alquran.

\section{DAFTAR PUSTAKA}

Abdurrazak, Y. b. (2004). Cara Mudah Menghafal Al Quran. Jakarta: Sabilia Press.

Abdurrochman, M. (2010). Analisis Efektifitas Metode Tahfidz Al-Quran. Bogor: Universitas Djuanda.

Ali, M. (1991). Ta'limul Muta'allim versi Imam Zarkasyi. Ponorogo: Tri Murti.

Al-Mubarakfuri, S. (2012). Tafsir Ibu Katsir. Bogor: Pustaka Ibnu Katsir.

As-Shiddieqqy, M. H. (2009). Ilmu-ilmu Alquran. Jakarta: Bulan Bintang.

Attulaimat, A. M. (2000). Halaqah AlQuraniah. Jeddah: Dar Nur Al Maktabah.

Badwilan, A. S. (2012). Kisah-kisah Inspiratif Para Penghafal Al-Quran. Solo: Wacana Ilmiah Press.

Bisri, H. (2013). Evaluasi Program Kader Dakwah Dalam Pencapaiaan Visi Kampus Bertauhid Universitas Djuanda Bogor. Jakarta: UNJ.

Chalik, C. A. (2007). Ulumul Quran. Jakarta: Diadit Media.

Depdikbud. (1996). Kamus Besar Bahasa Indonesia. Jakarta: Balai Pustaka.
Depdiknas. (2008). KUBI Pusat Bahasa. Jakarta: PT Gramedia Pustaka Utama.

Dhofier, Z. (2011). Tradisi Pesantren. Jakarta: LP3ES.

Hidayatullah. (2010). Memoar Penghafal Al Quran. Depok: Tauhid Media Center.

Husein, S. A. (2003). Aktualisasi Nilai Nilai Al Quran dalam Sistem Pendidikan Islam. Jakarta: Ciputat Press.

LPMA. (2011). Profil Lembaga Tahfidz AlQuran di Nusantara. Jakarta: LPMA.

Munir, M. (2005). Ilmu dan Seni Qiroatil Quran. Semarang: Binawan Pustaka Iltizam.

Musrif. (2014, Januari 15). Program Tahfidz Bina Madani. (B. Abdillah, Pewawancara)

Nizar, S. A. (2008). Sejarah dan Dinamika Lembaga-Lembaga Pendidikan Islam di Nusantara. Jakarta: Kencana Prenada.

Qomar, M. (2005). Pesantren dari Transformasi Metodologi Menuju Demokrasi Institusi . Jakarta: Erlangga.

Sa'dullah. (2008). Sembilan Cara Praktis Menghafal Al Quran. Jakarta: Gema Insani. Smith, M. K. (2009). Teori Pembelajaran dan Pengajaran. (A. Q. Shaleh, Penerj.) Yogyakarta: Mirza Media Pustaka.

Syarbani, A. (2014). Model Pendidikan Karakter dalam Keluarga. Jakarta: Elex Media Komputindo.

Widoyoko, S. E. (2012). Evaluasi Program Pembelajaran. Yogyakarta: Pustaka Pelajar.

Zarkasyi, A. S. (2005). Gontor dan Pembaharuan Pendidikan Pesantren. Jakarta: Raja Grafindo Persada.

Zuhairini. (2000). Sejarah Pendidikan Islam. Jakarta: Bumi Aksara. 